\title{
ANALISIS FAKTOR-FAKTOR YANG MEMENGARUHI TIMELINESS PUBLIKASI LAPORAN KEUANGAN PERIODE 2009-2010 (Studi Empiris Pada Bursa Efek Indonesia)
}

\author{
Sigit Mareta \\ Fakultas Ekonomi dan Bisnis Universitas Mercu Buana Jakarta \\ Email:maretasigit@gmail.com
}

\begin{abstract}
The purpose of this research is to analyze factors that affect timeliness of the Indonesian public company's financial statement forwarding. The examined factors of this research are profitability, liquidity, leverage, firms size, auditor opinion, reputation of public accountant, public accountant exchange, and management exchange as independent variables while timeliness as dependent variable. The Population of this research are all issuer at the Indonesian stock exchange that provides financial report for the period 2009 to 2010. The sample of this research are the company in the period was late to publish financial report, so obtained 97 companies. The method of purposive sampling and regression analysis logistics, are use for election sample. The variable timing, reputation of public accountant (Big4), public accountant exchange, the auditors opinion, and the management exchange are measured by dummy and other variables as ROA, CR, and DER measured by the ratio. The result of this research provides evidence that profitability and auditor opinion have influence on by significance to timeliness of financial statement forwading. However there is no evedence that liquidity, leverage, firms size, auditor opinion, reputation of public accountant, public accountant exchange, and management exchange have influence on timeliness of financial statement forwading.
\end{abstract}

Key words: timeliness, financial statement, profitability, liquidity, leverage, firms size, auditor opinion, reputation of public accountant, public accountant exchange, and management exchange.

\begin{abstract}
Abstrak: Tujuan dari penelitian ini adalah untuk menganalisis faktor-faktor yang mempengaruhi ketepatan waktu publikasi laporan keuangan perusahaan publik di Indonesia. Faktor yang diteliti dalam penelitian ini adalah profitabilitas, likuiditas, leverage, ukuran perusahaan, opini auditor, reputasi akuntan publik, pertukaran akuntan publik, dan pertukaran manajemen sebagai variabel independen sedangkan ketepatan waktu sebagai variabel dependen. Populasi dari penelitian ini adalah seluruh emiten di Bursa Efek Indonesia yang menyampaikan laporan keuangan untuk periode tahun 2009 sampai 2010. Sampel penelitian ini perusahaan pada periode tersebut pernah terlambat mempublikasikan laporan keuangan, sehingga diperoleh sampel 97 perusahaan. Pemilihan sampel menggunakan metode purposive sampling dan analisis yang digunakan adalah analisis regresi logistik. Variabel ketepatan waktu, reputasi akuntan publik (Big4), pergantian Kantor Akuntan Publik, opini auditor, dan pergantian manajemen diukur menggunakan dummy dan variabel lain $R O A, C R, D E R$ dan diukur dengan menggunakan rasio. Hasil penelitian ini memberikan bukti bahwa profitabilitas dan opini auditor memiliki pengaruh signifikan terhadap ketepatan waktu publikasi laporan keuangan.
\end{abstract}


Namun, tidak ditemukan bukti bahwa likuiditas, leverage, ukuran perusahaan, opini auditor, reputasi akuntan publik (Big4), pergantian Kantor Akuntan Publik, dan pergantian manajemen berpengaruh terhadap ketepatan waktu publikasi laporan keuangan.

Kata kunci: ketepatan waktu, laporan keuangan, profitability, likuiditas, leverage, ukuran perusahaan, opini auditor, reputasi akuntan publik (Big4), pergantian Kantor Akuntan Publik, dan pergantian manajemen.

\section{PENDAHULUAN}

Dalam perdagangan saham, informasi mempunyai peranan penting terutama bagi para investor yang akan melakukan aktivitas investasi di pasar modal. Melonjaknya jumlah perusahaan yang telah go publik menjadi indikasi bahwa perkembangan pasar modal sangat cepat. Ketepatan waktu (timeliness) pelaporan keuangan menjadi sangat penting bagi pemakai informasi (users) untuk membuat keputusan investasi.Dalam rangka memenuhi prinsip keterbukaan dan sesuai Keputusan Nomor 40/BL/2007, perihal Kewajiban Penyampaian Laporan Keuangan Berkala maka keterlambatan penyampaian laporan keuangan yang sudah diaudit paling lambat sembilan puluh hari atau tiga bulan sejak berakhirnya tahun buku. Jika perusahaan tidak tepat dalam menyampaikan laporan keuangan tersebut akan dikenakan sanksi administratif berupa denda Rp1.000.000,- per hari dengan jumlah maksimal Rp500.000.000,-. Namun demikian, masih ada beberapa perusahaan yang tidak dapat menyampaikan laporan keuangan secara tepat waktu. Hal ini terbukti bahwa pada tahun 2009 terdapat 31 perusahaan dan tahun 2010 terdapat 30 perusahaan yang tidak tepat waktu dalam penyampaian laporan keuangan. Oleh karena itu perlu ditelusuri faktor-faktor apa yang mempengaruhi ketepatan waktu penyampaian laporan keuangan pada perusahaan-perusahaan tersebut.

Dalam pembuatan laporan keuangan harus disajikan dengan relevan agar dapat digunakan sebagai pengambilan keputusan ekonomi. Relevan berarti informasi tersebut dapat dijadikan acuan bagi pengguna laporan keuangan dalam membuat keputusan ekonomi. Pembuatan keputusan ekonomi dilakukan dengan mengevaluasi peristiwa yang terjadi di masa lalu, saat sekarang maupun masa yang akan datang (IAI, 2012). Ketepatan waktu (timeliness) merupakan salah satu indikator dari relevansi. Ketepatan waktu (timeliness) adalah informasi yang ada siap untuk digunakan sebelum kehilangan makna oleh pemakai laporan keuangan serta kapasitasnya masih tersedia dalam pengambilan keputusan (IAI, 2012).

Dalam penelitian Suharli dan Harahap (2008) menemukan bahwa ROI dan KAP Big4 berpengaruh secara signifikan terhadap ketepatan waktu penyampaian laporan keuangan suatu perusahaan. Oleh karena itu, dari penelitian tersebut peneliti ingin mengkaji lebih dalam apakah ada faktor-faktor lain yang mempengaruhi ketepatan waktu pelaporan keuangan perusahaan, sehingga dalam penelitian ini ditambahkan beberapa faktor yang diprediksi dapat mempengaruhi ketepatan waktu pelaporan keuangan suatu perusahaan seperti leverage, likuiditas, opini audit, lamanya perusahaan menjadi klien KAP, serta pergantian manajemen.

Rumusan masalah yang akan penulis bahas adalah faktor-faktor apa saja yang dominan berpengaruh terhadap ketepatan waktu publikasi laporan keuangan tahunan 
emiten periode 2009-2010 (profitability, likuiditas, leverage, ukuran perusahaan, penggunaan KAP besar Big4, opini audit, lamanya perusahaan menjadi klien KAP, dan pergantian manajemen).

Adapun tujuan dari penulisan laporan penelitian ini adalah: (1) Mendiskripsikan tingkat ketepatan waktu pelaporan yang dipatuhi oleh perusahaan-perusahaan di Bursa Efek Indonesia; (2) Menemukan bukti secara empiris bahwa faktor-faktor tersebut (profitability, likuiditas, leverage, ukuran perusahaan, penggunaan KAP besar Big 4, opini audit, lamanya perusahaan menjadi klien KAP, dan pergantian manajemen) berpengaruh terhadap ketepatan waktu pelaporan keuangan perusahaan di Bursa Efek Jakarta.

Adapun kontribusi dalam penelitian ini sebagai berikut: (1) Untuk praktisi manajemen perusahaan, analis laporan keuangan, investor, kreditur, akan memberikan gambaran serta temuan-temuan tentang tingkat ketepatan waktu dalam melaporkan keadaan keuangan perusahaan. (2) Untuk akademisi, akan memberikan arah studi tentang konsep dasar akuntansi umumnya dan memperkuat pandangan ketepatan waktu (timeliness) pelaporan keuangan perusahaan di pasar modal khususnya. (3) Untuk organisasional BAPEPAM, BEI, dan lembaga yang turut andil dalam pengambilan kebijakan di pasar modal, akan menjadi masukan dalam membuat aturan, menetapkan sangsi dan denda serta arah kebijakan waktu pelaporan yang lebih sesuai, dalam meminimalisir tingkat keterlambatan pelaporan sesuai schedule.

\section{KAJIAN TEORI}

Teori Keagenan. Menurut Jensen dan Meckling dalam Widaryanti (2011), menggambarkan hubungan agency sebagai suatu kontrak dibawah satu atau lebih antara pemilik (principal) yang melibatkan manager (agent) untuk melaksanakan beberapa layanan bagi mereka dengan melibatkan pendelegasian wewenang pengambilan keputusan kepada manager (agent). Hal ini bertujuan agar hubungan kontraktual dapat berjalan dengan tanpa hambatan. Dengan adanya perencanaan kontrak yang tepat, maka akan terjadi keselarasan kepentingan antara manajer dan pemilik dan dalam hal konflik kepentingan ini yang merupakan inti dari agency theory.

Teori Kepatuhan. Peraturan tentang Kewajiban Penyampaian Laporan Keuangan Berkala secara hukum menginformasikan adanya kepatuhan setiap individu maupun organisasi (perusahaan publik) yang terlibat di pasar modal Indonesia untuk menyampaikan laporan keuangan tahunan perusahaan secara tepat waktu kepada Bapepam. Hal tersebut sesuai dengan teori kepatuhan (compliance theory).

Laporan Keuangan. Laporan keuangan merupakan laporan yang berisi informasi tentang keadaan keuangan suatu entitas sekaligus merupakan alat komunikasi aktivitas keuangan entitas tersebut (Fess dkk, 2005). Adapun jenis laporan keuangan yang lazim dikenal adalah Neraca, Laporan rugi laba, Laporan Perubahan Modal, Laporan Arus Kas dan Catatan atas Laporan Keuangan. Menurut Jumingan (2008), akuntansi merupakan language of business karena akuntansi (laporan keuangan) dapat dipakai sebagai alat komunikasi dengan pihak-pihak yang berkepentingan dengan data keuangan perusahaan. 
Ketepatan Waktu. Ketepatan waktu merupakan salah satu cara untuk mengukur transparansi dan kualitas pelaporan keuangan. Menurut Rachmawati (2008), penyampaian informasi sedini mungkin sangat diperlukan agar dapat dipakai sebagai dasar dalam pengambilan keputusan ekonomi dan mencegah agar terlambatnya pembuatan keputusan tersebut.

Profitability. Profitability adalah mengukur kemampuan perusahaan untuk menghasilkan keuntungan (profitabilitas), baik dalam hubungan dengan penjualan, asset dan modal saham tertentu. Profitability yang rendah menunjukkan bahwa tingkat kinerja manajemen perusahaan tersebut rendah atau kurang baik (Hanafi dan Halim, 2005). Tingkat profitability yang rendah merupakan berita buruk maka manajemen cenderung tidak melaporkan laporan keuangan secara tepat waktu dan jika tingkat profitability tinggi maka pihak manajemen akan cenderung melaporkan secara tepat waktu. Oleh karena itu, tepat waktu atau tidaknya pelaporan keuangan sangat dipengaruhi oleh isi dari laporan keuangan tersebut. Dalam penelitian ini, profitability diproksikan dengan return on assets (ROA).

Likuiditas. Likuiditas merupakan kemampuan perusahaan dalam melunasi kewajiban jangka pendeknya saat jatuh tempo. Penelitian Suharli dan Rachpiliani (2006) memberikan bukti empiris bahwa likuiditas mempengaruhi ketepatan waktu penyampaian laporan keuangan perusahaan dan memiliki hubungan searah. Perusahaan yang memiliki kemampuan yang tinggi dalam melunasi kewajiban jangka pendeknya. Hal ini merupakan berita baik (good news) sehingga perusahaan dengan kondisi seperti ini cenderung untuk tepat waktu dalam penyampaian laporan keuangannya.

Leverage. Debt to Equity ratio merupakan rasio utang yang digunakan untuk mengukur perbandingan antara total kewajiban dengan total ekuitas. Menurut Ifada (2009), tingginya tingkat leverage menunjukkan bahwa perusahaan tersebut memiliki risiko keuangan yang tinggi. Hal ini mengindikasikan bahwa perusahaan bersangkutan tengah mengalami kesulitan keuangan. Dengan adanya kesulitan keuangan tersebut maka perusahaan cenderung menunda penyampaian laporan keuangannya.

Ukuran Perusahaan. Ukuran perusahaan dalam penelitian ini diukur berdasarkan besar aset yang dimiliki oleh perusahaan tersebut. Menurut Sudarmadji dan Sularto (2007), total assets dipilih sebagai proksi dari variabel ukuran perusahaan karena total assets lebih stabil dan representatif dalam menunjukkan ukuran perusahaan dibandingkan dengan kapitalisasi pasar dan penjualan yang sangat dipengaruhi oleh permintaan dan penawaran. Suatu perusahaan yang mempunyai aset besar akan memiliki banyak sumber informasi, sumberdaya manusia dan sistem informasi yang canggih sehingga memungkinkan perusahaan tersebut melaporkan laporan keuangan secara cepat ke publik.

Kantor Akuntan Publik. Kategori KAP the big four di Indonesia antara lain: 1). KAP Price Waterhouse Coopers, yang bekerjasama dengan KAP Haryanto Sahari dan rekan. 2). KAP KPMG (Klynveld Peat Marwick Goerdeler), yang bekerjasama dengan KAP Siddharta-Siddharta dan Widjadja. 3). KAP Ernst and Young, yang bekerjasama dengan KAP Purwantono, Sarwoko dan Sandjadja. 4). KAP Deloitte Touche Thomatsu, yang 
bekerjasama dengan KAP Osman Bing Satrio dan rekan. Menurut Fahmi \& Hadi (2011), Pernyataan KAP sangat dipengaruhi dari segi kelayakan pada saat laporan keuangan dan hasil audit lainnya bahwa secara aturan dan prosedural dapat dinyatakan telah memenuhi syarat go public, maka dalah hal ini reputasi seorang auditor juga dipertaruhkan karena jika suatu perusahaan bermasalah pada laporan keuangannya maka auditor berserta KAPnya tersebut yang akan mengalami efek negatifnya seperti turunnya reputasi yang dimiliki. Oleh karena itu semakin besar suatu KAP maka akan memiliki reputasi yang baik dalam opini publik.

Opini Audit. Menurut Standar Profesi Akuntan Publik per 31 Maret 2011 (PSA 29 SA Seksi 508) dalam Fahmi dan Hadi (2011), ada lima jenis pendapat akuntan, antara lain: 1). Pendapat wajar tanpa pengecualian (Unqualified Opinion). 2). Pendapat wajar tanpa pengecualian dengan bahasa penjelasan (Unqualified Opinion report with Explanatory Language). 3). Pendapat wajar dengan pengecualian (qualified opinion). 4). Pendapat tidak wajar (Adverse Opinion). 5). Pernyataan tidak memberikan pendapat (Disclaimer of Opinion). Apabila selama pelaksanaan pekerjaan lapangan auditor tidak menemukan masalah atau penyimpangan maka auditor mungkin dapat dengan cepat menyelesaikan tugasnya dan segera mengeluarkan opini audit yang sesuai dengan hasil yang diperoleh.

Lamanya Perusahaan Menjadi Klien KAP. Pergantian akuntan publik dilakukan oleh perusahaan karena telah berakhirnya kontrak kerja yang disepakati antara Kantor Akuntan Publik dengan pemberi tugas dan telah memutuskan untuk tidak memperpanjang dengan penugasan baru. Semakin lama perusahaan diaudit oleh suatu KAP yang sama maka KAP tersebut tidak perlu lagi melakukan pemahaman-pemahaman mendasar mengenai bisnis klien.

Pergantian Manajemen. Pergantian manajemen seharusnya mampu memicu peningkatan kinerja perusahaan tersebut. Menurut Arogyaswammy (1995) dalam Smith dan Graves (2005), Perubahan tim manajemen senior adalah usaha dalam memperbaiki kepercayaan stakeholders yaitu usaha menjaga dukungan dari mereka. Diharapkan manajer senior yang baru dapat memberikan pandangan segar terhadap sebab-sebab penurunan dan memberikan kemampuan serta motivasi yang diperlukan dalam perubahan organisasi.

Penelitian Terdahulu. Adapun ringkasan penelitian terdahulu yang telah disajikan pada Tabel 1 sebagai berikut:

Tabel 1. Penelitian Terdahulu

\begin{tabular}{|c|c|c|c|}
\hline Peneliti & Tahun & Topik & Hasil Penelitian \\
\hline $\begin{array}{l}\text { Dyer \& McHugh } \\
\text { (dalam Oktorina } \\
\text { dan Suharli) }\end{array}$ & 2005 & $\begin{array}{l}\text { Profil ketepatan } \\
\text { waktu pelaporan dan } \\
\text { normalitas } \\
\text { keterlambatan }\end{array}$ & $\begin{array}{l}\text { - Ukuran Perusahaan \& tanggal } \\
\text { berakhirnya tahun buku berpengaruh } \\
\text { terhadap ketepatan waktu. } \\
\text { - Profitabilitas tidak signifikan } \\
\text { mempengaruhi ketepatan waktu. }\end{array}$ \\
\hline
\end{tabular}




\begin{tabular}{|c|c|c|c|}
\hline Peneliti & Tahun & Topik & Hasil Penelitian \\
\hline Utami, Wiwik & 2006 & $\begin{array}{l}\text { Faktor-faktor yang } \\
\text { mempengaruhi } \\
\text { keterlambatan } \\
\text { publikasi laporan } \\
\text { tahunan emiten }\end{array}$ & $\begin{array}{l}\text { Kerugian tahun berjalan secara } \\
\text { signifikan berpengaruh terhadap } \\
\text { keterlambatan publikasi laporan } \\
\text { tahunan emiten. }\end{array}$ \\
\hline $\begin{array}{l}\text { Suharli,M dan } \\
\text { Harahap, S.S }\end{array}$ & 2008 & $\begin{array}{l}\text { Ketepatan waktu } \\
\text { pelaporan keuangan } \\
\text { di Indonesia }\end{array}$ & $\begin{array}{l}\text { - Profitability dan akuntan big } 4 \\
\text { secara signifikan berpengaruh } \\
\text { terhadap ketepatan waktu pelaporan } \\
\text { keuangan. } \\
\text { - Ukuran perusahaan dan return tinggi } \\
\text { secara signifikan tidak berpengaruh } \\
\text { terhadap ketepatan waktu pelaporan } \\
\text { keuangan. }\end{array}$ \\
\hline
\end{tabular}

Kerangka Pemikiran. Perkembangan aktivitas di Bursa Efek Indonesia kini berkembang pesat, Namun pada nyatanya masih banyak perusahaan yang masih mengalami keterlambatan penyampaian laporan keuangan perusahaan, sehingga dalam hal ini perlu dikaji lebih dalam faktor-faktor apa saja yang mempengaruhi ketepatan waktu pelaporan keuangan suatu perusahaan. Pada gambar 1 menunjukkan hubungan antar variabel penelitian.

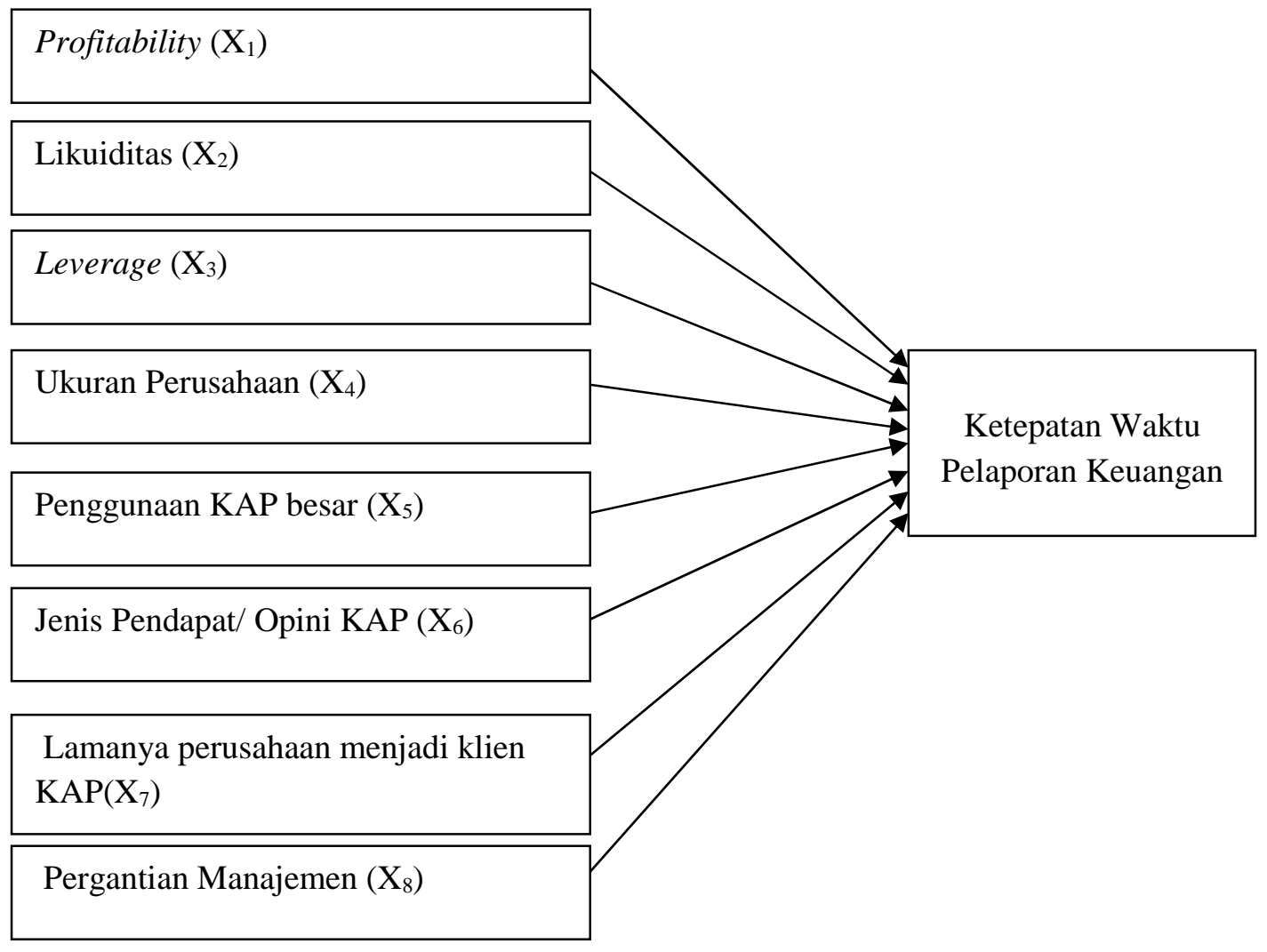

Gambar 1. Hubungan Antar Variabel Penelitian 
Profitability dan ketapatan Waktu Pelaporan Keuangan. Menurut Hilmi dan Ali (2008), perusahaan yang memiliki profitabiltas tinggi dapat dikatakan bahwa laporan keuangan perusahaan tersebut mengandung berita baik dan perusahaan yang mengalami berita baik akan cenderung cepat dalam menyampaikan laporan keuangannya dan sebaliknya jika profitabilitas perusahaan rendah maka hal ini merupakan berita buruk sehingga perusahaan cenderung telat atau tidak tepat waktu dalam menyampaikan laporan keuangannya.

Likuditas dan ketepatan Waktu Pelaporan Keuangan. Perusahaan yang mempunyai alat-alat likuid yang besar, maka perusahaan tersebut akan mampu memenuhi semua hutang jangka pendek yang segera harus dipenuhi, berarti perusahaan tersebut dalam keadaan likuid. Sedangkan perusahaan yang mempunyai alat-alat likuid kecil, maka perusahaan tersebut akan sulit untuk memenuhi hutang-hutang jangka pendeknya, berarti perusahaan tersebut dalam keadaan illikuid.

Leverage dan Ketepatan Waktu Pelaporan Keuangan. Menurut Rachmawati (2008), leverage atau solvabilitas berpengaruh signifikan terhadap ketapatan waktu dalam publikasi laporan keuangan (timeliness). Jika proporsi yang besar dari hutang terhadap total aktiva akan meningkatkan kecenderungan kerugian dimana semakin tinggi proporsi hutang maka akan semakin tinggi pula risiko kerugiannya. Dengan terjadinya hal tersebut maka auditor perlu meningkatkan kehati-hatian dalam mengaudit laporan keuangan perusahaan tersebut.

Ukuran Perusahaan dan Ketepatan Waktu Pelaporan Keuangan. Semakin besar ukuran perusahaan diharapkan dapat memiliki kemampuan yang lebih cepat dalam menyampaikan kemampuan yang lebih cepat dalam menyampaikan laporan keuangan, karena perusahaan yang besar tentu memiliki sumber daya lebih banyak, terutama staf keuangan atau akuntansi dengan didukung oleh teknologi yang canggih dan sistem pengendalian intern yang cukup kuat.

Penggunaan KAP besar dan Ketapatan Waktu Pelaporan Keuangan. Menurut Loeb (1971) dalam Hilmi dan Ali (2008) menyebutkan bahwa kantor akuntan publik besar memiliki akuntan yang berperilaku lebih etikal daripada akuntan dikantor akuntan publik kecil. Dengan demikian, kantor akuntan besar lebih memiliki reputasi yang baik dalam melakukan pekerjaan audit dan memberikan opini publik.

Opini Audit dan Ketepatan Waktu Pelaporan Keuangan. Perusahaan yang mendapat unqualified opinion dari auditor untuk laporan keuangannya cenderung akan lebih tepat waktu dalam menyampaikan laporan keuangannya karena unqualified opinion merupakan berita baik dari auditor dan sebaliknya jika perusahaan menerima opnini selain unqualified opinion maka hal tersebut merupakan berita buruk bagi perusahaan dan cenderung akan memperlambat penyampaian laporan keuangan.

Lamanya Perusahaan Menjadi Klien KAP dan Ketapatan Waktu Pelaporan Keuangan. Kantor Akuntan Publik dalam proses pengauditan suatu perusahaan untuk 
pertama kalinya perlu melakukan pemahaman yang memadai tentang bisnis utama klien, pengendalian intern, struktur organisasi, dan lain sebagainya. Semakin lama perusahaan diaudit oleh suatu KAP yang sama, maka KAP tersebut tidak perlu lagi melakukan pemahaman-pemahaman mendasar mengenai bisnis klien.

Pergantian Manajemen dan Ketepatan Waktu Pelaporan Keuangan. CEO mempunyai peranan penting dalam hal pengambilan keputusan strategis bagi perusahaan. Seorang CEO harus memiliki kompetensi yang baik dalam pengambilan keputusan yang cepat dan tepat, dapat meminimalisir risiko bisnis dan meningkatkan profit perusahaan. Jika terjadi pergantian CEO atau pergantian pada tingkatan top management tentunya akan mempengaruhi kinerja perusahaan, karena masing-masing CEO tentu memiliki kompetensi yang berbeda, sehingga akan berpengaruh terhadap hasil pengambilan keputusan perusahaan.

Perumusan hipotesis. Adapun hipotesis dalam penelitian ini adalah sebagai berikut:

$\mathrm{H}_{1}$ : Profitability secara signifikan berpengaruh terhadap ketepatan waktu pelaporan keuangan Perusahaan.

$\mathrm{H}_{2}$ : Likuiditas secara signifikan berpengaruh terhadap ketepatan waktu pelaporan keuangan perusahaan.

$\mathrm{H}_{3}$ : Leverage secara signifikan berpengaruh terhadap ketepatan waktu pelaporan keuangan perusahaan.

$\mathrm{H}_{4}$ : Ukuran perusahaan secara secara signifikan berpengaruh terhadap ketepatan waktu pelaporan keuangan perusahaan.

$\mathrm{H}_{5}$ : Penggunaan Kantor Akuntan Publik besar (Big4) secara signifikan berpengaruh terhadap ketepatan waktu pelaporan keuangan perusahaan.

$\mathrm{H}_{6}$ : Jenis Pendapat/opini audit Kantor Akuntan Publik secara signifikan berpengaruh terhadap ketepatan waktu pelaporan keuangan perusahaan.

$\mathrm{H}_{7}$ : Lamanya perusahaan menjadi klien Kantor Akuntan Publik secara signifikan berpengaruh terhadap ketepatan waktu pelaporan keuangan perusahaan.

$\mathrm{H}_{8}$ : Pergantian Manajemen secara signifikan berpengaruh terhadap ketepatan waktu pelaporan keuangan perusahaan.

\section{METODE}

Jenis Penelitian. Jenis penelitian kausal yaitu penelitian yang bertujuan untuk menguji hipotesis tentang pengaruh satu atau beberapa variabel (variabel independen) terhadap variabel lainnya (variabel dependen).

Populasi dan Sampel Penelitian. Metode pengambilan sampel dengan menggunakan purposive sampling. Syarat yang digunakan untuk memilih sampel adalah sebagai berikut: (1) Termasuk perusahaan publik yang pernah terlambat mempublikasikan laporan keuangan pada tahun 2009 dan 2010. (2) Menerbitkan laporan keuangan tahunan (annual report) yang berakhir pada tanggal 31 Desember selama periode pengamatan 2009-2010. (3) Memiliki ketersediaan data tanggal penyampaian laporan keuangan maupun data 
laporan keuangan yang lengkap terkait dengan variabel-variabel yang digunakan dalam penelitian.

Teknik pengumpulan Data. Teknik pengumpulan data pada penelitian ini dilakukan melalui penelusuran data sekunder dengan kepustakaan dan manual. Data tersebut diperoleh di kantor Bapepam, www.idx.co.id yang merupakan website/situs resmi Bursa Efek Indonesia (BEI), Pojok BEI Universitas Mercu Buana.

Metode Analisis Data. Uji hipotesis dilakukan secara multivariate dengan menggunakan regresi logisticuntuk menguji hipotesis sebagai berikut :

$\mathrm{L} n \frac{\mathrm{T} L}{1-\mathrm{T} L}=\beta 0+\beta_{1} \mathrm{X} 1+\beta_{2} \mathrm{X} 2+\beta_{3} \mathrm{X} 3+\beta_{4} \mathrm{X} 4+\beta_{5} \mathrm{X} 5+\beta_{6} \mathrm{X} 6+\beta_{7} \mathrm{X} 7+\beta_{8} \mathrm{X} 8+\varepsilon$

Keterangan:

$\mathrm{T} L$

Ln $-\quad$ Dummy variabel ketepatan (kategori 0 untuk perusahaan yang tidak tepat

1-TL waktu dan kategori 1 untuk perusahaan yang tepat waktu).

$\mathrm{X} 1=$ profitability $; \quad \mathrm{X} 2=$ likuiditas $; \mathrm{X} 3=$ leverage $; \mathrm{X} 4=$ ukuran perusahaan; $\mathrm{X} 5=$ Penggunaan KAP Besar (Big4); X6 = jenis opini audit/pendapat audit; X7 = lamanya perusahaan menjadi klien KAP; X8 = pergantian manajemen; $\beta=$ koefisien regresi; $\varepsilon$ = variabel gangguan.

\section{HASIL DAN PEMBAHASAN}

Uji Hipotesis. Pengujian hipotesis menggunakan model logistic regression dengan metode enter pada tingkat signifikan $(\alpha) 10 \%$.

Menilai Kelayakan Model Regresi (goddness of test). Analisa awal yang harus dilakukan adalah menilai kelayakan model regresi. Perhatikan nilai goddness of fit test pada tabel 2 yang diukur dengan nilai Chi-square pada bagian bawah uji Hosmer and Lemeshow, diperoleh angka probabilitas sebesar 0,822, dimana 0,822 >0,05, maka Ho diterima. Hal ini berarti bahwa model regresi layak dipakai untuk analisis selanjutnya, karena tidak ada perbedaan yang nyata antara klasifikasi yang diprediksi dengan klasifikasi yang diamati.

Tabel 2. Hosmer and Lemeshow Test

\begin{tabular}{lccc}
\hline Step & Chi-square & df & Sig. \\
\hline 1 & 4.377 & 8 & .822 \\
\hline
\end{tabular}

Langkah selanjutnya menilai keseluruhan model (overall model fit). Pada tabel 3 angka -2 Log Likelihood (LL), di mana pada awal (Block Number $=0)$ angka -2 LL adalah 
127,954, sedangkan pada tabel 4 Block Number $=1$ angka -2 LL turun menjadi 118,422. Penurunan log likelohood ini menunjukkan bahwa model regresi yang baik.

\section{Tabel 3. Interation History}

Iteration History $\mathrm{a}^{\mathrm{a}, \mathrm{b}, \mathrm{c}}$

\begin{tabular}{rrcc}
\hline & & Coefficients \\
\cline { 4 - 4 } Iteration & -2 Log likelihood & Constant \\
\hline Step 0 & 1 & 127.957 & -.515 \\
& 2 & 127.954 & -.527 \\
3 & 127.954 & -.527 \\
\hline
\end{tabular}

a. Constant is included in the model.

b. Initial -2 Log Likelihood: 127.954

c. Estimation terminated at iteration number 3 because parameter estimates changed by less than .001 .

Tabel 4 menunjukkan nilai Cox \& Snell R Square sebesar 0.094 dan nilai Negelkerke $\mathrm{R}$ sebesar 0,128 yang berarti variabelitas variabel dependen yang dapat dijelaskan oleh variabelitas variabel independen sebesar $13 \%$.

Tabel 4. Negelkerke R Square

Model Summary

\begin{tabular}{|c|c|c|c|}
\hline Step & $\begin{array}{c}-2 \log \\
\text { likelihood }\end{array}$ & $\begin{array}{c}\text { Cox \& Snell R } \\
\text { Square }\end{array}$ & Nagelkerke R Square \\
\hline 1 & $118.422^{\mathrm{a}}$ & .094 & .128 \\
\hline
\end{tabular}

a. Estimation terminated at iteration number 4 because parameter estimates changed by less than .001 .

Tabel klasifikasi 2 × 2 menghitung nilai estimasi yang benar dan salah. Pada kolom merupakan dua nilai prediksi dari variable dependen tepat waktu dan tidak tepat waktu, sedangkan pada baris menunjukkan nilai obeservasi sesungguhnya dari variable dependen tepat waktu dan tidak tepat waktu seperti terlihat pada Tabel 5.

Tabel 5 menunjukkan bahwa pada kolom prediksi perusahaan tepat waktu sebanyak 36 perusahaan, sedangkan pada baris, hasil observasi sesungguhnya perusahaan tepat waktu sebanyak 10 perusahaan, sedangkan untuk perusahaan tidak tepat waktu sebanyak 61 perusahaan, dan pada baris hasil observasi sesungguhnya perusahaan tidak tepat waktu sebanyak 54 perusahaan. Jadi, ketepatan model ini secara keseluruhan sebesar $66 \%$. 
Tabel 5. Clasification Table

Classification Table ${ }^{\mathrm{a}}$

\begin{tabular}{|c|c|c|c|c|c|}
\hline & & & Predicted & & \\
\hline & & & TIMELINES & & \\
\hline & Observed & & $\begin{array}{l}\text { Tidak Tepat } \\
\text { Waktu }\end{array}$ & Tepat Waktu & Correct \\
\hline Step & TIMELINESS & Tidak Tepat Waktu & 54 & 7 & 88.5 \\
\hline 1 & & Tepat Waktu & 26 & 10 & 27.8 \\
\hline & Overall Percent & age & & & 66.0 \\
\hline
\end{tabular}

a. The cut value is .500

Pada tahap akhir adalah uji koefisien regresi. Hasil pengujian koefisien regresi dapat dilihat pada Tabel 6 .

Tabel 6. Hasil Uji Hipótesis

\begin{tabular}{clcccc}
\hline No & \multicolumn{1}{c}{ Variabel } & B & S.E. & Wald & Signifikansi \\
\hline 1 & Roa & 10,623 & 5,245 & 4,094 & 0,043 \\
2 & Cr & $-0,174$ & 0,132 & 1,722 & 0,189 \\
3 & Der & 0,031 & 0,146 & 0,045 & 0,831 \\
4 & Size & 0,015 & 1,464 & 1,177 & 0,204 \\
& Lamanya Perusahaan Menjadi & $-0,544$ & 0,506 & 1,157 & 0,282 \\
& Klien Kap & $-0,182$ & 0,550 & 0,109 & 0,741 \\
6 & Kap Big4 & 1,200 & 0,709 & 2,864 & 0,091 \\
7 & Opini Audit & $-0,78$ & 0,494 & 0,025 & 0,875 \\
8 & Pergantian Manajemen & & & & \\
\hline
\end{tabular}

Pengujian multivariate dengan regresi logistik atas seluruh variabel terlihat bahwa ada dua variabel yang nilai signifikansinya lebih kecil dari 0,10 yaitu variabel Profitability yang diukur dengan ROA dan variabel Opini audit. Pada ROA diperoleh Wald 4,094 (Sig. 0,043) dan opini audit diperoleh Wald 2,864 (Sig. 0,091). Hasil ini menunjukkan bahwa kedua variabel berpengaruh terhadap ketepatan waktu pelaporan keuangan perusahaan pada level $10 \%$.

Profitability dan Ketepatan Waktu Pelaporan KeuanganPerusahaan. Hasil pengujian regresi logistik menunjukkan bahwa variabel profitability yang diproksi dengan ROA memiliki probabilitas 0,043. Karena angka 0,043 lebih kecil dari 0,1 maka variabel profitability yang diproksi dengan $R O A$ dinyatakan signifikan secara statistik. Hal ini berarti bahwa profitability yang diproksi dengan ROA berpengaruh terhadap ketepatan waktu pelaporan keuangan perusahaan, hubungan ini bertanda positif. Hal ini berarti bahwa profit yang tinggi merupakan berita baik bagi perusahaan sehingga perusahaan cenderung tidak akan menunda pelaporan informasi keuangannya. 
Likuiditas dan Ketepatan Waktu Pelaporan Keuangan Perusahaan. Pengujian atas variabel likuiditas yang diproksi dengan current ratio $(C R)$ ditemukan bukti empiris bahwa current ratio secara signifikan tidak berpengaruh terhadap ketepatan waktu pelaporan keuangan perusahaan ke Bapepam. Hal ini dapat dilihat dalam hasil uji regresi logistik dimana variabel current ratio mempunyai angka probabilitas (signifikansi) 0,189 diatas $0,1(10 \%)$.

Perbedaan hasil temuan ini dapat terjadi karena perusahaan yang mempunyai tingkat likuiditas yang tinggi, belum tentu menyampaikan laporan keuangannya dengan tepat waktu. Oleh karena itu, dalam penelitian ini antara perusahaan yang tepat waktu maupun perusahaan yang tidak tepat waktu sebagian besar melaporkan laporan keuangan secara tepat waktu untuk menghindari persepsi negatif oleh kreditor terhadap kinerja perusahaan.

Leverage dan Ketepatan Waktu Pelaporan Keuangan Perusahaan. Hasil pengujian regresi logistik menunjukkan bahwa variabel leverage yang diproksi dengan debt to equity ratio(DER) memiliki probabilitas 0,831 . Karena angka 0,831 lebih besar dari $0,1(10 \%)$ maka variabel leverage yang diproksi dengan $D E R$ dinyatakan tidak signifikan secara statistik. Hal ini berarti bahwa leverage yang diproksi dengan DER tidak berpengaruh terhadap ketepatan waktu pelaporan keuangan perusahaan. Hal ini dapat terjadi karena diindikasikan bahwa perusahaan yang tepat waktu maupun perusahaan yang tidak tepat waktu mengabaikan informasi tentang debt to equity ratio (DER).

Ukuran Perusahaan dan Ketepatan Waktu Pelaporan Keuangan Perusahaan. Hasil pengujian logistic regression antara variabel ukuran perusahaan yang diproksi dengan total aktiva, memiliki probabilitas 0,204 diatas 0,1 (10\%) sehingga dinyatakan tidak signifikan secara statistik. Hal ini berarti bahwa tidak ada pengaruh ukuran perusahaan terhadap ketepatan waktu pelaporan keuangan perusahaan.Pada hakikatnya ketepatan waktu dipengaruhi oleh seberapa besar rasa tanggung jawab perusahaan dalam menaati peraturan yang ditetapkan oleh Bapepam tentang keterbukaan informasi, dalam hal ini ketepatan waktu pelaporan keuangan perusahaan sebagai tanggung jawab perusahaan dalam memberikan informasi kondisi perusahaan kepada pihak-pihak yang berkepentingan dengan perusahaan, untuk tujuan analisa keuangan dalam rangka menentukan keputusan investasi dan ketepatan waktu sangatlah penting.

\section{Lamanya Perusahaan Menjadi Klien KAP dan Ketepatan Waktu Penyampaian Pelaporan Keuangan Perusahaan. Pengujian atas variabel pergantian KAP ditemukan bukti empiris bahwa pergantian KAP secara signifikan tidak berpengaruh terhadap ketepatan waktu pelaporan keuangan perusahaan ke Bapepam. Hal ini dapat dilihat dalam hasil uji regresi logistik dimana variabel lamanya perusahaan menjadi klien KAP mempunyai angka probabilitas (signifikansi) 0,282 diatas 0,1 (10\%). \\ Perbedaan hasil temuan ini dapat terjadi karena perusahaan yang tidak mengalami pergantian KAP, belum tentu menyampaikan laporan keuangannya dengan tepat waktu. Sebaliknya, perusahaan yang mengalami pergantian KAP juga ingin menyampaikan laporan keuangannya dengan tepat waktu, yang bertujuan agar pihak kreditor dapat segera mengetahui kinerja perusahaan dengan cepat dari laporan yang telah diterbitkan atau dilaporkan secara tepat waktu.}


Penggunaan KAP Besar (Big4) dan Ketepatan Waktu Pelaporan Keuangan Perusahaan. Pengujian atas variabel penggunaan KAP besar (Big4) ditemukan bukti empiris bahwa penggunaan KAP besar (Big4) secara signifikan tidak berpengaruh terhadap ketepatan waktu pelaporan keuangan perusahaan ke Bapepam. Hal ini dapat dilihat dalam hasil uji regresi logistik dimana variabel penggunaan KAP besar (Big4) mempunyai angka probabilitas (signifikansi) 0,741 diatas 0,1 (10\%).

Dari hasil penelitian ini, sebagian besar perusahaan baik yang tepat waktu atau tidak tepat waktu dalam pelaporan keuangan perusahaan diaudit oleh Kantor Akuntan Publik yang termasuk The Big Four. Namun, terdapat juga perusahaan yang menggunakan jasa KAP selain The Big Four yang menyampaikan laporan keuangannya dengan tepat waktu. Hal ini menunjukkan bahwa tidak ada jaminan dalam ketepatan waktu pelaporan keuangan perusahaan dengan informasi tentang kualitas auditor.

Opini audit dan Ketepatan Waktu Pelaporan Keuangan Perusahaan. Pengujian atas variabel opini audit ditemukan bukti empiris bahwa opini audit secara signifikan berpengaruh terhadap ketepatan waktu pelaporan keuangan perusahaan ke Bapepam. Hal ini dapat dilihat dalam hasil uji regresi logistik dimana variabel opini auditmempunyai angka probabilitas (signifikansi) 0,091 dibawah 0,1 (10\%), hubungan ini bertanda positif.

Tabel 7. Matriks Jenis Opini Audit Perusahaan yang Menjadi Sampel Penelitian

\begin{tabular}{ccccccc}
\hline No & Laporan Keuangan & \multicolumn{4}{c}{ Jenis Opini Audit } & Jumlah \\
\cline { 3 - 6 } & $\begin{array}{c}\text { Unqualified } \\
\text { Opinion }\end{array}$ & $\%$ & $\begin{array}{c}\text { Selain } \\
\text { Unqualified } \\
\text { Opinion }\end{array}$ & $\%$ & Junn \\
\hline 1 & Tepat Waktu & 32 & 40,51 & 4 & 22,22 & 36 \\
2 & Tidak Tepat Waktu & 47 & 59,49 & 14 & 77,78 & 61 \\
& Jumlah & 79 & 100 & 18 & 100 & 97 \\
\hline
\end{tabular}

Ketepatan penyampaian laporan keuangan berhubungan erat dengan opini audit yang diberikan auditor karena perusahaan yang mendapat unqualified opinion dari auditor untuk laporan keuangannya cenderung akan lebih tepat waktu dalam menyampaikan laporan keuangannya karena unqualified opinion merupakan berita baik dari auditor dan sebaliknya jika perusahaan menerima opnini selain unqualified opinion maka hal tersebut merupakan berita buruk bagi perusahaan dan cenderung akan memperlambat penyampaian laporan keuangan dan hal tersebut tentu dapat memberikan keraguan bagi investor dalam pengambilan keputusan investasi.

Pergantian Manajemen dan Ketepatan Waktu Pelaporan Keuangan Perusahaan. Pengujian atas variabel pergantian manajemen ditemukan bukti empiris bahwa pergantian manajemen secara signifikan tidak berpengaruh terhadap ketepatan waktu pelaporan keuangan perusahaan ke Bapepam. Hal ini dapat dilihat dalam hasil uji regresi logistik dimana variabel pergantian manajemenmempunyai angka probabilitas (signifikansi) 0,875 diatas $0,1(10 \%)$. 
Hasil penelitian ini juga tidak sejalan dengan teori yang dikemukakan oleh Arogyswammy (1995) dalam Smith \& Graves (2005), perubahan tim senior manajemen adalah tahapan penting dalam berhasilnya perbaikan kondisi perusahaan. Dalam hal ini peranan kebijakan pimpinan menjadi sangat penting dalam arah kemajuan perusahaan, dimana kesalahan pengambilan keputusan akan sangat berdampak pada keterpurukan perusahaan.

\section{PENUTUP}

Simpulan. Setelah dilakukan langkah-langkah analisa ketepatan waktu pelaporan keuangan maka, ada beberapa kesimpulan dari hasil penelitian ini, yaitu: (1) Variabel Profitability dan opini audit berpengaruh terhadap ketepatan waktu pelaporan keuangan perusahaan di Bursa Efek Indonesia. (2) Variabel likuiditas, leverage, ukuran perusahaan, penggunaan KAP besar Big4, lamanya perusahaan menjadi klien KAP, dan pergantian manajemen tidak berpengaruh terhadap ketepatan waktu pelaporan keuangan perusahaan di Bursa Efek Indonesia.

Saran. Dalam penelitian ini terdapat beberapa keterbatasan. Adapun keterbatasan dalam penelitian ini adalah: (1) Periode penelitian hanya dua tahun sehingga hasil penelitian kurang dapat menggambarkan kondisi yang sesungguhnya atau tidak bisa melihat kecenderungan yang terjadi jangka panjang, kemudian akan menggambarkan kondisi sesungguhnya selama jangka waktu panjang. (2) Penelitian ini menggunakan variabelvariabel yang hanya berkaitan dengan data internal perusahaan sehingga kondisi eksternal yang diperkirakan dapat mempengaruhi penelitian ini secara tidak terkontrol. (3) Kriteria metode purposive sampling yang kurang tepat mengakibatkan sebagian perusahaan tidak diikutsertakan sehingga hasil penelitian kurang menggambarkan kondisi yang sesungguhnya.

Adanya beberapa keterbatasan dalam penelitian ini, maka untuk penelitian selanjutnya perlu dilakukan: (1) Memperpanjang periode penelitian. Periode penelitian sebaiknya lebih dari dua tahun untuk dapat membedakan faktor-faktor apa saja yang berpengaruh terhadap ketepatan waktu pelaporan dalam jangka waktu beberapa tahun sehingga akan dapat menggambarkan kondisi yang sesungguhnya terjadi. (2) Menambahkan variabel dari kondisi eksternal perusahaan yang diduga turut mempengaruhi ketepatan waktu. (3) Menggunakan alat ukur lain untuk melihat kompleksitas operasi perusahaan seperti diversifikasi jalur produk, serta lini bisnis.

Implikasi. Hasil penelitian menemukan bukti empiris bahwa variabel profitability (ROA) dan opini audit berpengaruh terhadap ketepatan waktu penyampaian pelaporan keuangan perusahaan. Hal ini dapat dijadikan acuan bagi para investor, para analis keuangan, pihak manajemen, dan kreditur untuk melihat kinerja perusahaan yaitu suatu perusahaan yang mempunyai profit tinggi akan cenderung lebih cepat dalam menyampaikan pelaporan keuangannya. Laporan keuangan sebagai acuan untuk pengambilan keputusan untuk melakukan investasi, sehingga dengan adanya penelitian ini, maka perlu diperhatikan dalam hal pembuatan laporan keuangan yang benar agar mudah dipahami oleh pemakai laporan keuangan tersebut serta menghasilkan informasi yang memiliki kualitas relevan. Bapepam dapat memberikan sangsi yang lebih tegas dan memberikan efek jera, agar 
perusahaan yang masih mengalami keterlambatan penyampaian pelaporan keuangan perusahaan semakin berkurang hingga tidak ada lagi perusahaan yang mengalami keterlambatan penyampaian laporan keuangan.

\section{DAFTAR RUJUKAN}

Agoes, Sukrisno. (2012) Auditing Petunjuk Praktis Pemeriksaaan Akuntan oleh Akuntan Publik. Jakarta: Salemba Empat. Hal. 75.

Almilia, Luciana Spica dan Lucas Setiady. (2006) "Faktor-faktor yang Mempengaruhi Penyelesaian Penyajian Laporan Keuangan pada Perusahaan yang Terdaftar di BEJ". Seminar Nasional Good Corporate Governance.Jakarta:Universitas Trisakti.

Brigham, Eugene F. and Houston, Joel F. (2006) Fundamentals of Financial Management. $10^{\text {th }}$ Edition. South-Western.

Fahmi, Irham dan Hadi L. Yovi. (2011) Teori Portofolio dan Analisis Investasi. Teori dan Soal Jawab. Bandung: Penerbit Alfabeta.

Fees, Reeve, Warren. (2005) Pengantar Akuntansi, Edisi 21. Jakarta: Salemba Empat.

Ghozali, Imam. (2006) Aplikasi Analisis Multivariate dengan program SPSS. Semarang. Badan Penerbit Universitas Diponegoro.

Hanafi, Mamduh M. dan Abdul Halim. (2005) Analisis Laporan Keuangan. Edisi Kedua. Yogyakarta: UPP AMP YKPN.

Ikatan Akuntansi Indonesia. (2012) Standar Akuntansi Keuangan. Jakarta: Salemba Empat.

Jumingan. (2008) Analisis Laporan Keuangan. Jakarta: PT. BUMI AKSARA. Hal 1

Kadir, Abdul. (2008) "Faktor-faktor yang Berpengaruh Terhadap Ketepatan Waktu Pelaporan Keuangan”. Tesis Tidak Dipublikasikan. Fakultas Ekonomi Universitas Diponegoro.

Kasmir. (2008) Bank dan Lembaga Keuangan Lainnya. Edisi Revisi 2008. Jakarta: PT. RAJAGRAFINDO PERSADA.

Kelton, (2008) "The Impact of corporate governance on Internet financial reporting," Journal of Accounting and Public Police, 27 pp.62-87.

Malcolm Smith dan Christopher Graves, (2005) "Corporate Turnaround and Financial Distress," Managerial Auditing Journal,Vol 20, (3), pp.304-320.

Oktorina, Megawati dan Michell Suharli. (2005) "Studi Empiris Terhadap Faktor Penentu Kepatuhan Ketepatan Waktu Pelaporan Keuangan". Jurnal Ekonomi dan Bisnis. Vol. 5. (2) hal.119-132

Rachmawati, Sistya. (2008) "Pengaruh Faktor Internal dan Eksternal Perusahaan terhadap Audit Delay dan Timeliness". Jurnal Akuntansi dan Keuangan. Vol.10, (1).

Sekaran, Uma. (2006) Metodologi Penelitian Untuk Bisnis. Edisi Empat, Buku Satu. Jakarta: Salemba Empat.

Shamsul Nahar Abdullah, (2006) "Board Structure and Ownership in Malaysia:The Case of Distress Listed Companies", Corporate Governance Bradford, Vol. 6, Iss.5,P582.

Sudaryanti, Nunik. (2008) "Faktor-Faktor yang Mempengaruhi Ketepatan Waktu Pelaporan Keuangan Perusahaan Manufaktur di Bursa Efek Indonesia”. Skripsi tidak dipublikasikan. Fakultas Ekonomi Universitas Diponegoro. 
Suharli, Michell dan Harahap.S.S. (2008) "Timeliness Laporan Keuangan di Indonesia (Studi Empiris Terhadap Emiten Bursa Efek Indonesia”. Jurnal Media Riset Akuntansi, Auditing, dan Informasi. Vol. 8 (2). pp 97-116.

Utami, Wiwik. (2006) "Keterlambatan Publikasi Laporan Tahunan Emiten: Kajian Empiris di Bursa Efek Yakarta”. Jurnal Kajian Akuntansi. Vol. 1. (1) Juni. Pp. 1428.

Ukago, Kristianus. (2005) "Faktor-Faktor yang Berpengaruh Terhadap ketepatan Waktu Pelaporan Keuangan Bukti Empiris Emiten di Bursa Efek Yakarta”. Jurnal Maksi. Hal. 13-33

Widaryanti. (2011) “Analisis Faktor-Faktor yang mempengaruhi ketepatan waktu Corporate Internet Reporting pada Perusahaan yang terdaftar di Bursa Efek Indonesia”. Jurnal Ilmu Manajemen \& Akuntansi Terapan. Vol.2 (2). 